\title{
Help, I Want to Know What My MBA Students Want:
}

\section{A Study of French MBA Students}

\author{
Douglas K. Peterson \\ Business without Borders, The NGO/NPO Institute, Inc. \\ $610134^{\text {th }}$ St. West, Suite 4H, Bradenton, Florida, USA \\ E-mail: Peterson@business-without-borders.org
}

\begin{abstract}
A major challenge facing schools who teach MBA programs is developing a degree of student satisfaction and commitment. While MBA education is different than undergraduate the predictors of student satisfaction are probably different as well. This study charts some predictors of student satisfaction with their programs using an unconventional measure: the job satisfaction index, and the organizational commitment questionnaire. Moderators of classroom style, age, and gender of professor are explored. Explanatory and predictive relationships are revealed through multiple regression.
\end{abstract}

Keywords: Education, MBA, Satisfaction, Commitment, Satisfaction and Commitment elements

\section{Introduction}

There are increasing emphases placed on student satisfaction among public, private and proprietary schools. In part this is because students are paying higher tuition costs and develop high service expectations. When dissatisfied, students are known to complain bitterly to administration or walk to the university across the street. As a result, academic life and competition has become rather keen.

Growing budgets require feeding. While public institutions rely on tax subsidies for funding, private schools depend almost wholly upon student tuition to pay for operational, instructional, and facilities costs. In these tight economic times more and more public schools depend upon capita reimbursement as support is hitting a critical low. In order to cut costs, colleges and universities adapt their processes and reprioritize, cutting things like study abroad trips and depending upon transient and adjunct labor while stepping up foundation activities to provide funding. Their behavior is very similar to consumer product companies: cut costs and processes, while measuring customer satisfaction. When customer satisfaction goes down, cuts in services and product attributes stop.

The purpose of this paper is to help determine what helps predict student satisfaction and retention in colleges and universities. The unit of analysis is the MBA student, and predictors of satisfaction and commitment are the Job Satisfaction Index, and the Organizational Commitment Questionnaire. The outcome is that this study should help administration formulate an understanding of how students develop program related attitudes. By developing this understanding administrators can leverage to enhance attributes of satisfaction and commitment while engaging processes to generate increased quality and efficiency of labor, and secure motivation among MBA students in an academic program.

The study examines the components of commitment and job satisfaction among MBA students and examines their perception of what constitutes classroom leadership and the role of what attending a "good school" does for student motivation. The research methodology for this study is cross sectional, though plans are in place to make it longitudinal. It is multi-trait and multi-method (MTMM) in that it uses focus groups and empirical data. Multi-methods, questionnaires, interviews, and observational data were collected over a 1-month period and English language standardized focus-validated questionnaires were utilized. Researcher and company-employed observers were utilized to look for student behaviors during multiple classes. The objective of this MTMM methodology was to gain depth of understanding, while adding to the literature the much broader methodology that would be needed for organizational behavior and educational scholars to develop the micro-level content area. There is no study in existence like this one.

\section{Cultural Differences}

According to Hofstede (1984) there would be some significant cultural characteristics among students in France. Were we to use Hofstede's (1984) dimensions, we would find that the French student is probably very strong on 
uncertainty avoidance, highly individualistic, accepting of central power structures, and has a fair middle ground on masculine and feminine ideals. Were professors to interpret the information, prima facae, they might assume that students prefer to be:

- "Given specific directions from above for individual assignments. Not handling group assignments well. There may be a chit chat factor."

- "Provided with individual level incentive programs with specific criteria, performance decided by someone higher than them."

- "Given specific criteria for class and for graduation."

- "Led through material structure and shown consideration which mixes the "you do" with the "let's help" scenario, seen in the classroom."

If the typologies available in the literature are true, professors should be able to get a good start on effectively managing their classroom dynamic by imagining an application of a stable cultural typology and putting that application into practice. Both experience and academic literature suggests things aren't that simple. When scholars research cultural differences and spend time in host country facilities, they find the suggested typologies amount to little more than researched stereotypes.

The management of the classroom, and the actions taken wind up being a great deal more complicated than cultural typologies would suggest. Students show some relatively surprising characteristics in relationship to the cultural stereotypes and measurements of national culture. They do want to know exactly what to do in the classroom setting. Ambiguity tends to throw the class dynamic askew into chatty anarchy. The more this happens, satisfaction, participation, and classroom/program commitment can suffer. Leader behaviors of initiating structure and consideration are likely found to be correlated with commitment and the perception of programmatic quality, according to one manager. Perhaps this is why French students appear to need powerful leadership to maintain the direction and structured focused behavior. Were we to accept the proposition that French students were uncertainty avoiding, power distance accepting, individualistic, and masculine/feminine we might assume that students study class satisfaction and commitment would be related to Hofstedian stereotypes. In practice this could materialize as a desire for strong supervision, specific work rules, group incentives and training, strong central management while the classroom that is treated with some egalitarianism. One cannot rule out that some lessons of this study seem to be that it is context in the classroom that was predictive of satisfaction and commitment, but also culture. (Teagarden \& VonGlinow, 1990). The main objectives of this study are to:

- To explore important class attitudes and learning motivations among French students.

- To delve into whether it is national culture, scholastic culture or both that influences the development of student study, attitudes and motivation.

- To expand the research methodology in international research to include MTMM methodology.

- To report on the findings that the components of job attitudes and motivation.

\section{Classroom Satisfaction Attitudes in France}

\subsection{Organizational Commitment/Job Satisfaction}

Organizational Commitment is the relative strength of an individual's identification with and involvement in a particular organization (Meyer and Allen, 1987; Mowday, Porter, and Steers, 1982). Conceptually, it can be characterized by (1) the strong belief in and acceptance of organizational goals and values; (2) a willingness to exert considerable effort on behalf of the organization; and (3) a strong desire to maintain membership in the organization (Mowday, Porter, and Steers, 1982).

Commitment is characterized as an attitude of attachment to an employing organization. Researchers focus primarily on the identification of antecedents contributing to the development of organizational commitment and the impact on job attitudes and behavior that commitment may have (Meyer and Allen, 1987). According to Angle and Lawson, (1993) there are antecedents to commitment that can be split into components of personal characteristics and situational factors. Personal characteristics include variables like gender, age, and employment tenure. Situational factors include variables like job characteristics, organizational characteristics, work situations, and work experiences that employees may have.

There has been a great volume of work relating to organizational commitment in academic literature, but none to classroom commitment in this paradigm. Recent reviews of the commitment research (Mathieu and Zajac, 1990; 
Meyer and Allen, 1987; Reichers, 1985) reveal that most research relates to the antecedents, correlates, and consequences of organizational commitment. Outside of the primary geographic base, which is located in the United States, Canada, Asia, and Western Europe, scholastic interest in commitment and job satisfaction is increasing, but that phenomenon is relatively recent. According to Randall (1993), researchers on commitment and job satisfaction are entering an international phase where they are beginning to explore, extend, and apply theories abroad. Although various regions have been explored (primarily in the Pacific Rim, North America, Western Europe and the Middle East), interest in Latin America, Eastern Europe, the FSU, and Indian Subcontinent has been lacking, but is now on the increase. In the existing literature, commitment is supposed to have a strong impact on student turnover and performance. Because of the growth of proprietary educational facilities at the graduate level in France, antecedents and consequences to commitment among students in France should be explored regarding whether they are valid and have similar impacts on student dropout, acceptance of scholastic values, and willingness to exert effort. By understanding the nature of commitment among French students, we may begin to honestly understand the impact that the work, the professor, the rewards, the potential for graduation and co-classmates have on commitment. This article can help develop our knowledge and ability to explain, predict and control attitudes and behaviors among students and further understand their concerns.

\subsection{Antecedents to Organizational Commitment}

Literature on organizational commitment predicts that the personal characteristics of age, gender, and occupational status (as either line or staff) will predict levels of commitment among French students. The literature also predicts that situational factors like classroom participation, scholastic effectiveness, and leadership styles will also predict levels of commitment.

\subsubsection{Personal Characteristics}

Personal characteristics have been investigated in relationship to organizational commitment (Mathieu and Zajac, 1990). The most frequent investigation relating to personal characteristics in the international literature are gender, age, tenure, and education (Randall, 1993).

\subsubsection{Gender}

Mathieu and Zajac's (1990) research indicates that women in France tend to be more committed to organizations than men. Explanations for this finding are that jobs are more difficult to find; there are fewer options presented for employment; and that there are obstacles relating to marriage and family that make it more difficult for women to become organizational members (Aven, Parker, and McEvoy, 1993). Because of this, it makes sense to indicate that once acceptable employment is obtained, women tend to be more committed to it.

\subsubsection{Age}

In the academic literature centered on the USA, age and time spent in a workplace tend to be positively correlated with organizational commitment. As individuals get older, it is postulated that preference for alternative employment opportunities decreases while personal investments in the firm tend to increase. This promotes commitment to the organization (Allen and Meyer, 1993; Angle and Perry, 1981; Mathieu and Zajac, 1990; Mowday et al, 1082; Gregersen and Black, 1992).

People in France show cultural attitudes that value age. It doesn't come out in the literature, however, this study therefore suggests that age will have no impact.

\subsubsection{Situational Factors}

Situational factors are the second component of organizational commitment and are identified as antecedents to commitment. Typically, situations that affect commitment are those that are related to characteristics of work, characteristics of an organization, and experiences that students have while on the job (Price et al, 2001; Glisson and Durick, 1988; Gregersen and Black, 1992; Mowday et al, 1982).

\subsubsection{Job Characteristics}

Job characteristics that are related to commitment are those facets of a job that affect individual affect and job attitudes (Johnston et al, 1990; Mathieu and Hamel, 1989). It is postulated that situations that present role conflict, role ambiguity and limited job scope have a dampening effect on organizational commitment. In the literature related to international organizational commitment (Randall, 1993), it is noted that ambiguity, conflict and scope have different dampening effects depending upon culture and individual differences.

One controversy in the literature relates to the role that job satisfaction, as measured by the Job Diagnostic Index has on commitment. While Bateman and Strasser, (1984) would argue that job satisfaction is a result of commitment rather than a cause of it, Reichers (1985) argues the opposite. 
This study postulates the same relation as Peterson (1997): that job satisfaction will be positively correlated with commitment in French organizations. It will be interesting to note which elements of job satisfaction are the most related. Measurement instruments, like the JDI postulate that job satisfaction is created from satisfaction with work, supervision, payment, ascension, and students. This is an adaptation of the JDI scope and intent. This study is the only one in the world that does that. It is postulated that elements that more closely relate to an individual student's daily work activities will have greater salience in predicting job satisfaction and commitment. In this case, it is proposed that satisfaction with supervision, students, and payment will have a greater impact on satisfaction and commitment than satisfaction with work and promotion.

There are several organizational characteristics that are positively related to commitment (see Mowday et al, 1982). Of these, organizational effectiveness seems particularly relevant because of the focus on efficiency and adaptation (Mott, 1972). The more effective an organization can make itself in its achievement, the higher will be the level of commitment on the part of its employees.

\subsubsection{Work Experience}

An additional situational antecedent of commitment represents those work experiences that occur while an employee works with an organization. Researchers have cited leader behavior and participative decision making as having significant effects on commitment (Glisson and Durick, 1988; Mathieu and Zajac, 1990; Randall, 1993).

Leadership behaviors generally are characterized in terms of initiating structure and consideration, both of which show positive correlation with organizational commitment among North American students (Page \& Wiseman, 1993; Mathieu and Zajac, 1990). Initiating structure includes behaviors concerned with productivity, planning, coordination, discipline, clarification, and problem solving (Yukl, 1981). It is anticipated that these behaviors will be correlated with organizational commitment in French organizations because employees want to be closely supervised (DeForest, 1994) in a paternalistic manner (Morris and Pavett, 1992; Schuler et al, 1996). Employees expect a clear definition of job responsibility and are more loyal because of it (Davis, 1971).

Consideration includes behaviors concerned with supportiveness, consultation, representation, and recognition (Yukl, 1981). It is expected these behaviors are correlated with organizational commitment in French organizations because employees become loyal and hardworking when they feel they are appreciated by supervisors who are human relations oriented (Kras, 1989; McKinniss and Natella, 1994; Schuler et al, 1996).

Researchers have found participative decision making to be an antecedent condition to commitment in a number of domestic and international studies (Randall, 1993). According to Salancik (1977) participation in decision making increases organizational commitment by increasing felt responsibility and by influencing the extent to which employees make committed choices.

Traditionally, students in the United States expect participation in decision making. It is assumed that students in France expect authority figures to make decisions and assume responsibility for those decisions (Morris and Pavett, 1992; Schuler et al, 1996). Things may be changing, though. While students desire for their organizations to be effective, they are beginning to accept that their participation may influence job security and therefore pay incentive systems. Contrary to previous studies, this study expects to find a positive relationship between participation and commitment in French organizations.

\subsubsection{Effectiveness}

The relationship between effectiveness and commitment may be changing. Peterson (1997) postulated a negative relationship between effectiveness and commitment in French organizations. Schuler et al (1996) suggest that as schools become more selective students in France develop lower levels of commitment because they perceive they are working harder for fewer rewards. If there is a connection between effectiveness and commitment on the part of French students, it is probably due to the notion that schools who are perceived as being more effective are known as "better places to study". This paper proposes that effectiveness will be positive in its relationship to commitment and satisfaction because employees crave/ perceive status and stability in their work relationships. Pursuit of efficiency, on the other hand, done wrong, will be predict lower desire to expend greater effort for the organization. Efficiency programs done correctly, that is those that provide great communication and that address student's desires for uncertainty avoidance, will not attenuate commitment. Hofstede (1997) predicts that French students are high in their propensity for uncertainty avoidance, they will prefer more certainty and predictability. Assuming that organizational effectiveness contributes to uncertainty and runs counter to students' desire to "do only what can be done reasonably", one might think that effectiveness (as defined by efficiency and adaptability) would be negatively correlated with commitment. This paper will propose that this is not true. 


\section{Method}

\subsection{Participants}

This study was conducted among subjects in a proprietary business school located in Paris and in several other cities around the world. The professor invited students to participate in the research, and coordinated focus group activities as part of a research methods course. The typical subject in this case was a female graduate student has been or is currently employed. Length of employment in most cases was more than a year.

\subsection{Measures}

There were two methods of collecting data. First, there was a questionnaire adapted from Peterson (1997) consisting of an adaptation of widely recognized standard instruments with high reliabilities. These measures were designed to assess organizational commitment, job satisfaction, leader behavior, organizational effectiveness/efficiency and their antecedents. Specifically, Mowday's (1982) Organizational Commitment Questionnaire was implemented, along with Smith, Kendall and Holmes (1969) Job Diagnostic Index. Further, Mott's (1972) organizational effectiveness measure was implemented, and Yukl's (1981) Managerial Behavior Survey. Respondents used an English language version of each measure, although their first language generally was French. Focus groups validated questionnaire items as part of a class activity. This second method complemented the questionnaire. The researcher engaged in focus group interviews prior to collecting data. The purpose of the groups was to ascertain nuances involved in student motivation, to check the ongoing accuracy of the questionnaires and their construct validity, and to probe for additional concepts in student motivation not previously covered in the previous written literature. The interview technique was a modified cone structure that covered major topical areas in a structured format, which preserved the ability to probe for contextual detail, language nuance, and emotional content (D'Iribarne, 1997). It was in context with the class that the questionnaire and focus groups were administered.

This survey used the Organizational Commitment Questionnaire (OCQ) developed by Mowday et al (1982). The 18 item questionnaire was used. Because of its psychometric properties, this instrument is accepted in organizational behavior and researchers have used it in a great many published studies, of which 18 have been international in scope (Mathieu and Zajac, 1990; Randall, 1993). A coefficient alpha was computed to determine the internal consistency reliability for the construct within this study. The result was acceptable at .8416 .

Job characteristics were assessed using the Job Descriptive Index (Smith et al, 1969), which consists of 72 items. Cook, Hepworth, Wall and Warr (1981) suggested this index is most psychometrically acceptable as a measure of satisfaction. To complete the index, subjects were asked to indicate their satisfaction with five job components (work, pay, co-students, promotion and supervision) by rating whether listed items were descriptive of the respective dimensions. A global job satisfaction measure was formed by averaging the component scores (Porter et al, 1974; Teas, 1983). The resulting reliability analysis yielded an acceptable alpha of .8039.

Organizational characteristics were computed by using an Organizational Effectiveness Measure (Mott, 1972) consisting of eight items, each with five response categories which reflected strong to weak positions on each item. The reliability for this single construct was acceptable at .8713 .

Work experiences were assessed through the analysis of 11 additional items on the questionnaire. To determine leader behavior, 11 items were used from the Managerial Behavior Survey (Yukl, 1981). There were 6 items reflecting initiating structure and 5 items reflecting consideration. These yielded acceptable alphas of .9557 and 9382 , respectively.

Finally, in addition to the measures, the translated questionnaire included demographic variables like gender, age, years of education, and time in employment.

\section{Results}

Zero order correlation among major variables are presented in Table 1. While there are many correlations that are statistically significant, only a few exceed .6. This would make us think multicollinearity probably isn't an issue. To ensure that multicollinearity was not a problem in the regression model, a variance inflation factor (VIF) was computed for each independent variable. The largest VIF was around 7. According to Neter, Wasserman and Kutner (1989), if the maximum VIF exceeds 10, then multicollinearity may be unduly influencing the least squares estimates.

One way ANOVA was used to test the relationship between the dichotomous variable "gender" and the variables satisfaction, commitment, initiating structure, consideration, organizational effectiveness, and each of the commitment components: affective, behavioral, and continuance commitment. The following Table 2 presents 
the results of this ANOVA.

In this program, there were some differences between men and women in terms of commitment need for consideration and not structure, liking the program, doing the work and finishing. There was a significant difference in relationship to behavioral commitment, with women reporting a great deal more behavioral commitment than men.

To investigate further the relative strength of the relationships between the variables of satisfaction (as a construction of satisfaction with work, supervision, pay, promotion, and students), leadership behaviors (initiating structure and consideration), organizational effectiveness, and commitment along with its components (affective commitment, behavioral commitment, and continuance commitment), separate ANOVA and stepwise regressions were conducted. The analysis typifies the approach taken in the empirical tests of commitment (Bateman and Strasser, 1984). The results, in Tables 3-8, illustrate the range of variables in this study that account for significant portions of the commitment variance.

Students were far more likely to report study elements like this (a "+" means there is a statistically significant relationship. The characterization "lo" means the negative elements of the variable e.g. "work" (e.g. boring tedious, never ending): "Hi" represents the more positive elements of "work", like interesting, fascinating, fashionable: stimulating, and good. Table 9 highlights the characteristics:

\section{Discussion}

This study investigated the concept of program commitment among French MBA students, studying in Paris. The study forwards the thought that recognized measures of commitment and satisfaction yields broader insights into the international management education literature, which is not currently a well-researched area. The analysis reveals several variables that are significantly related to organizational commitment among students in France.

This study began with a set of general objectives, one of which was to "explore important work related attitudes among MBA students in a proprietary MBA program operating in France." Given that it would be incumbent upon the researcher to place the attitude exploration in cultural and organizational context, the effort was expended to spend adequate time in the host nation so that context could be correctly placed.

Previous literature (Peterson, 1997) suggests that employees in France might behave according to national cultural norms. It has been speculated that these employees would be ambiguity averse, masculine/feminine neutral, accepting of power distance, and collectivistic. Some of the logical extensions of this reasoning would have us predicting that French students are likely to accept directions from superiors, have equal participation rates in the workforce, desire work incentives and projects, and wish professors would spell out, in detail, directions for assignments. In all instances, literature calls for more research to either confirm of refute these propositions. Happily, most of the later research has refuted stereotypes of French students, while adding some empirical data that supports the development of positive student attitudes and motivation, along with a more accurate picture of student characteristics. The Peterson (1997) article, one of the first empirical studies of international work characteristics, supports the notion that women are equally committed to their efforts as are men, and that job satisfaction, participation in decisions, and age were predictive of organizational commitment. Of added interest, were the measurements that supported the connection between leadership behaviors and time in rank with commitment. This study goes a great deal further in that it finds significantly different results, with a data set that is more than about average in size (in comparison with other studies) with triangulated ethnographic data to support, and add context, to the conclusions, while conceptually splitting commitment into affective, behavioral and continuance commitment.

It is interesting to note that job satisfaction is predictive of commitment. With respect to situational factors, the weaker correlation between commitment and job satisfaction may be reflective of the short time the manufacturing facility has been operating. There is evidence that as a whole, students do develop greater levels of commitment the more satisfied they are with work, supervision, pay, promotions and colleagues. Focus groups indicated that employees in line capacities requested positive initiating structure and didn't separate initiating structure and consideration. A test for an interaction effect between initiating structure and consideration yielded better correlation than the consideration variable alone. This creates the impression that employees desire considerate initiating structure, but not initiating structure without consideration and (especially) not consideration without initiating structure. Given the prevailing literature on students as wishing to put time in, and not being overly concerned with scholastic work/production, one may be tempted to change that stereotype and design work and supervisory relationships that encourage work structure while showing consideration and encouragement to participate. Focus group interviews here reinforce that idea, as do 
observations.

Focus group interviews reinforce the conclusions of Peterson (1997), especially as relates to desire to provide feedback. Perhaps French students are becoming more used to providing input to the work processes because they realize that participation is encouraged and will not result in negative sanctions, like it might in traditional business education in France. Like Peterson (1997) this report concludes that employees in France will provide input when they can provide group input rather than individual feedback. The focus group studies in this research support that. Employees were loath to speak individually, but were quite talkative in groups.

Like the research of Peterson (1997), this research shows a positive relationship between perceived organizational effectiveness and commitment. Perhaps it is supported that a historical lack of concern for efficiency has indeed been changing. Perhaps employees are looking at the reputation of their firms in the community and because of that, are gaining satisfaction relating to the effectiveness of their effort. Focus group interviews bore this out across occupational categories. French students are beginning to create the realization that business practice is competitive and good jobs are hard to find. More study and data collection would be required.

Perhaps further research can provide insight into the theoretical connections between satisfaction and commitment for the French student. Literature reports that job satisfaction is certainly important for the French student. The focus groups reinforced that assertion. A student in the school, when speaking about commitment, indicated a phrase occasionally used. That phrase was "Je Suis Ici" which means, "I am here." For these students, having the shirt of commitment may indicate a bonding process with the scholastic environment. Providing job satisfaction, positive leadership behaviors, consistency, and predictability may go a long way toward inviting students to wear their shirts. Buying the shirt may help too, but doesn't guarantee the student will wear it. It may be that satisfaction as reported in a job that is culturally consistent (at least somewhat), may be the way allows employees to take ownership of the shirt, and want to wear it too.

Regarding the research, limitations should be kept in mind. The sample comes from one school. More measures are needed to validate these findings. Perhaps finding another school that has administrative and delivery centrally located in Paris would be better. In terms of research, this study is probably the first on MBA students in France every created. As a result, the generality of these results are minimal. Perhaps the working environment in this firm affected respondents' attitudes in way that may not be consistent with other students or organizations. As a result, more research is necessary to solidify findings. The longitudinal measures taken here help, and would indeed serve as a model for future research.

The findings have important implications for schools operating in France. The results of these studies suggests that administrators should determine the relevant factors that contribute to student satisfaction and commitment. By focusing on these factors, administrators and professors can enhance student commitment and satisfaction and therefore secure productive efforts among students in the cross-cultural environment. It is encouraging that French students are open to the ideas and commitment of work teams. They may find that by implementing such teams, they can develop strong commitment and thus minimize turnover.

\section{References}

Adler, N. (1997). International Dimensions of Organizational Behavior. New York: PWS-Kent.

Allen, N.J., \& Meyer, J.P. (1993). Organizational commitment: Evidence of career stage effects? Journal of Business Research, 26, 49-61.

Angle, H.L., \& Lawson, M.B. (1993). Changes in affective and continuance commitment in times of relocation. Journal of Business Research, 26, 3-15.

Angle, H.L., \& Perry, J.L. (1981). An empirical assessment of organizational commitment and organizational effectiveness. Administrative Science Quarterly, 26, 1-13.

Aven, F.F., Parker, B., \& McEvoy, G.M. (1993). Gender and attitudinal commitment to Organizations: A meta-analysis. Journal of Business Research, 26, 63-73.

Bartol, K.M. (1979). Professionalism as a predictor of organizational commitment, role, Stress and turnover: A multidimensional approach. Academy of Management Journal, 22, 815-821.

Bateman, T.S., \& Strasser, S. (1984). A longitudinal analysis of the antecedents of Organizational commitment. Academy of Management Journal, 27(1), 95-112.

Borycki, C., Thorn, R.G., \& Lemaster, J. (1997). Job Satisfaction and Organizational Commitment: A comparison of United States and France. International Journal of Commerce and Management, 8:3 p. 7-25. 
Boyacigiller, N., \& Adler, N.J. (1991). The parochial dinosaur: Organizational science in A global context. Academy of Management Review, 16(2), 262-290.Cook, J.D., Hepworth, S.J., Wall, T.D., \& Warr, P.B. (1981). The experience of work: A compendium and review of 249 measures and their use. London: Academic Press.

D'Iribarne, P. (1997). The usefulness of an ethnographic approach to the international comparison of organizations. International Studies of Management \& Organization, Winter 1996/1997; Vol. 26:4; pg. 30 - 48.

Davis, S.M. (1971). Comparative management: Organizational and cultural perspectives. Englewood Cliffs, NJ: Prentice-Hall.

Directory of American firms operating in foreign countries, $21^{\text {st }}$ Edition. (2002). New York: Uniworld Business Publications.

Glisson, C., \& Durick, M. (1988). Predictors of job satisfaction and organizational commitment in human service organizations. Administrative Quarterly, 33, 61-81.

Gregersen, H.B., \& Black, J.S. (1992). Antecedents to commitment to a parent company and a foreign operation. Academy of Management Journal, 35(1), 61-81.

Heusinkveld, P. (1994). Inside France. New York: Wiley.

Hofstede, G. (1984). Culture's Consequences: International Differences in Work Related Values. Newbury Park: Sage Publications

Hoppe, M.H. (1993). The effects of national culture on the theory and practice of Management. $R \& D$ Management, Vol. 23:4; pg. $313-326$.

Ichikawa, A. (1996). Leadership as a form of culture: Its present and future states in Japan. In R.M. Steers, L.W. Porter, and G.A. Bigley (eds) Motivation and Leadership at Work, $6 \mathrm{t}^{\mathrm{h}}$ Edition. (New York: McGraw-Hill)

Johnston, M.W., Parasuraman, A., Futrell, C.M., \& Black, W.C. (1990). A longitudinal assessment of the impact of selected organizational influences on salespeople's organizational commitment during early employment. Journal of Marketing Research, 27, 333-344.

Kelley, L., Whatley, A., \& Worthley, R. (1987). Assessing the effects of culture on managerial attitudes: A three culture test. Journal of International Business Studies, 18:2 p. 17-31.

Kras, E.S. (1989). Management in two cultures. Yarmouth, ME: Intercultural Press.

Lincoln, James R. (1996). Employee work attitudes and management practice in the U.S. and Japan: Evidence from a large comparative survey. In R.M. Steers, L.W. Porter, and G.A. Bigley (eds) Motivation and Leadership at Work, $6 \mathrm{t}^{\mathrm{h}}$ Edition. (New York: McGraw-Hill)

Mathieu, J.E., \& Hamel, K. (1989). A causal model of the antecedents of organizational commitment among professionals and nonprofessionals. Journal of vocational behavior, 34, 299-317.

Mathieu, J.E., \& Zajac, D.M. (1990). A review and meta-analysis of the antecedents, correlates, and consequences of organizational commitment. Psychological Bulletin, 108(2), 171-194.

McKinniss, C.B., \& Natella, A. (1994). Business in France: Managerial behavior, protocol, and etiquette. New York: Haworth Press.

Meyer, J.P., \& Allen, N.J. (1984). Testing the "side-bet story" of organizational commitment: Some methodological considerations. Journal of Applied Psychology, 69, 372-378.

Meyer, J.P., \& Allen, N.J. (1987). A longitudinal analysis of the early development and consequences of organizational commitment. Canadian Journal of Behavioral Science, 19, 199-215.

Morris, T., \& Pavett, C.M. (1992). Management style and productivity in two cultures. Journal of International Business Studies, 1, 169-179.

Mott, P.E. (1972). The characteristics of effective organizations. New York: Harper \& Row.

Mowday, R.T., Porter, L.W., \& Steers, R.M. (1982). Employee-organization linkages.San Diego, CA: Academic Press.

Neter, J., Wasserman, W., \& Kutner, M.H. (1989). Applied linear regression models. Homewood, IL: Irwin.

Newman, K.L. (1996). Culture and congruence: The fit between management practices and national culture. Journal of International Business Studies Vol. 27:4; pg. 753 - 780. 
Page, N.R., \& Wiseman, R.L. (1993). Supervisory Behavior and Student Satisfaction in the United States, France and Spain. Journal of Business Communication, 30:2, p. 161-180.

Peterson, D.K. (1997). A Test of Compensation Strategy Effects in Technology Organizations on Individual Local Pay-Status Value: A Proposed Relationship to Commitment, Satisfaction, and Attachment. Lincoln, Nebraska: University of Nebraska.

Porter, L.W., Steers, R.M., Mowday, R.T., \& Boulian, P.V. (1974). Organizational commitment, job satisfaction, and turnover among psychiatric technicians. Journal of Applied Psychology, 59, 603-609.

Price, K.H., Hall, T.W., Vanden Bos, K., \& Hunton, J.E. (2001) Features of the value function for voice and their consistency across participants from four countries: Great Britain, France, the Netherlands, and the United States. Organizational Behavior and Human Decision Processes, 84:1 p. 95-121.

Randall, D.M. (1993). Cross-cultural research on organizational commitment: A review and application of Hofstede's value survey module. Journal of Business Research, 26, 91-110.

Reichers, A.E. (1985). A review and reconceptualization of organizational commitment. Academy of Management Review, 10, 465-476.

Robbins, S.P. (1997). Management, 5th Edition. Englewood Cliffs, NJ: Prentice Hall, 1990, p. 670.

Salancik, G.R. (1977). Commitment and the control of organizational behavior and belief. In B.W. Staw \& G.R. Salancik (Eds.), New directions in organizational behavior. Chicago: St. Clair Press.

Smith, P.B. (1992). Organizational behavior and national cultures. British Journal of Management, Vol. 3:1; pg. $39-52$.

Smith, P.C., Kendall, L.M., \& Hulin, C.L. (1969). The measurement of satisfaction in work and retirement. Chicago; Rand McNally.

Teagarden, M.B., \& Von Glinow, M.A. (1990). Contextual Determinants of HRM Effectiveness in Cooperative Alliances: French Evidence. Management International Review. 30:1 p.23-36.

Teas, R.K. (1983). Supervisory behavior, role stress, and job satisfaction of industrial salespeople. Journal of Marketing Research, 20, 84-91.

Yukl, G.A. (1981). Leadership in organization. Englewood Cliffs, NJ: Prentice-Hall. 
Table 1. Means, Standard Deviations, and Correlations for All Variables

\begin{tabular}{|c|c|c|c|c|c|c|c|c|c|c|c|c|c|}
\hline & $N=66$ & Age & Gender & $\begin{array}{c}\text { Initiate } \\
\text { Structure }\end{array}$ & $\begin{array}{l}\text { Consid } \\
\text { eration }\end{array}$ & $\begin{array}{c}\text { Work } \\
\text { Sat }\end{array}$ & $\begin{array}{c}\text { Prof } \\
\text { Sat }\end{array}$ & $\begin{array}{c}\text { Reward } \\
\text { Sat }\end{array}$ & $\begin{array}{c}\text { Grad } \\
\text { Sat }\end{array}$ & $\begin{array}{c}\text { Class } \\
\text { Mate } \\
\text { Sat }\end{array}$ & $\begin{array}{l}\text { Affect } \\
\text { Com }\end{array}$ & $\begin{array}{c}\text { Behave } \\
\text { Com }\end{array}$ & $\begin{array}{c}\text { Contin } \\
\text { Com }\end{array}$ \\
\hline Age & $\begin{array}{l}\text { Pearson } \\
\text { Correlation } \\
\text { Sig. (2-tailed) }\end{array}$ & 1 & & & & & & & & & & & \\
\hline Gender & $\begin{array}{l}\text { Pearson } \\
\text { Correlation } \\
\text { Sig. (2-tailed) }\end{array}$ & $\begin{array}{r}-.065 \\
.094 \\
\end{array}$ & 1 & & & & & & & & & & \\
\hline $\begin{array}{l}\text { Initiat } \\
\text { Structure }\end{array}$ & $\begin{array}{l}\text { Pearson } \\
\text { Correlation } \\
\text { Sig. (2-tailed) }\end{array}$ & $\begin{array}{r}.215^{* *} \\
.000 \\
\end{array}$ & $\begin{array}{r}-.050 \\
.197 \\
\end{array}$ & 1 & & & & & & & & & \\
\hline $\begin{array}{l}\text { Consid } \\
\text { eration }\end{array}$ & $\begin{array}{l}\text { Pearson } \\
\text { Correlation } \\
\text { Sig. (2-tailed) }\end{array}$ & $\begin{array}{r}.235^{* *} \\
.000 \\
\end{array}$ & $\begin{array}{r}-.078^{*} \\
.043 \\
\end{array}$ & $\begin{array}{r}.839^{* *} \\
.000 \\
\end{array}$ & 1 & & & & & & & & \\
\hline $\begin{array}{l}\text { Work } \\
\text { Sat }\end{array}$ & $\begin{array}{l}\text { Pearson } \\
\text { Correlation } \\
\text { Sig. (2-tailed) }\end{array}$ & $\begin{array}{l}.076 \\
.050\end{array}$ & $\begin{array}{l}.023 \\
.547\end{array}$ & $\begin{array}{l}.051 \\
.193 \\
\end{array}$ & $\begin{array}{l}.037 \\
.337\end{array}$ & 1 & & & & & & & \\
\hline $\begin{array}{l}\text { Prof } \\
\text { Sat }\end{array}$ & $\begin{array}{l}\text { Pearson } \\
\text { Correlation } \\
\text { Sig. (2-tailed) }\end{array}$ & $\begin{array}{l}.030 \\
.440\end{array}$ & $\begin{array}{l}.009 \\
.819\end{array}$ & $\begin{array}{l}.027 \\
.496\end{array}$ & $\begin{array}{l}.010 \\
.803\end{array}$ & $\begin{array}{r}.795^{* *} \\
.000\end{array}$ & 1 & & & & & & \\
\hline $\begin{array}{l}\text { Reward } \\
\text { Sat }\end{array}$ & $\begin{array}{l}\text { Pearson } \\
\text { Correlation } \\
\text { Sig. (2-tailed) }\end{array}$ & $\begin{array}{l}.083^{*} \\
.032 \\
\end{array}$ & $\begin{array}{r}-.001 \\
.974 \\
\end{array}$ & $\begin{array}{l}.090^{*} \\
.021\end{array}$ & $\begin{array}{l}.039 \\
.310 \\
\end{array}$ & $\begin{array}{r}.747^{* *} \\
.000 \\
\end{array}$ & $\begin{array}{l}.696^{* *} \\
.000 \\
\end{array}$ & 1 & & & & & \\
\hline $\begin{array}{l}\text { Graduat } \\
\text { Sat }\end{array}$ & $\begin{array}{l}\text { Pearson } \\
\text { Correlation } \\
\text { Sig. (2-tailed) }\end{array}$ & $\begin{array}{r}.054 \\
.166 \\
\end{array}$ & $\begin{array}{l}.021 \\
.584 \\
\end{array}$ & $\begin{array}{l}.011 \\
.778 \\
\end{array}$ & $\begin{array}{r}-.036 \\
.359 \\
\end{array}$ & $\begin{array}{l}.749^{* *} \\
.000 \\
\end{array}$ & $\begin{array}{r}.756^{* *} \\
.000 \\
\end{array}$ & $\begin{array}{l}.820^{* *} \\
.000 \\
\end{array}$ & 1 & & & & \\
\hline $\begin{array}{l}\text { Classmate } \\
\text { Sat }\end{array}$ & $\begin{array}{l}\text { Pearson } \\
\text { Correlation } \\
\text { Sig. (2-tailed) }\end{array}$ & $\begin{array}{l}.063 \\
.105 \\
\end{array}$ & $\begin{array}{l}.006 \\
.881 \\
\end{array}$ & $\begin{array}{l}.024 \\
.539 \\
\end{array}$ & $\begin{array}{r}-.002 \\
.950 \\
\end{array}$ & $\begin{array}{l}.761^{* *} \\
.000 \\
\end{array}$ & $\begin{array}{l}.787^{* *} \\
.000 \\
\end{array}$ & $\begin{array}{l}.766^{* *} \\
.000 \\
\end{array}$ & $\begin{array}{l}.839^{* *} \\
.000 \\
\end{array}$ & 1 & & & \\
\hline $\begin{array}{l}\text { Affect } \\
\text { Commit }\end{array}$ & $\begin{array}{l}\text { Pearson } \\
\text { Correlation } \\
\text { Sig. (2-tailed) }\end{array}$ & $\begin{array}{l}.028 \\
.470\end{array}$ & $\begin{array}{r}-.092^{*} \\
.018\end{array}$ & $\begin{array}{l}.216^{* *} \\
.000\end{array}$ & $\begin{array}{l}.230^{* *} \\
.000\end{array}$ & $\begin{array}{r}.117^{* *} \\
.002 \\
\end{array}$ & $\begin{array}{r}.135^{* *} \\
.001 \\
\end{array}$ & $\begin{array}{l}.151^{* *} \\
.000\end{array}$ & $\begin{array}{l}.122^{* *} \\
.002\end{array}$ & $\begin{array}{r}.123^{* *} \\
.001\end{array}$ & 1 & & \\
\hline $\begin{array}{l}\text { Behave } \\
\text { Commit }\end{array}$ & $\begin{array}{l}\text { Pearson } \\
\text { Correlation } \\
\text { Sig. (2-tailed) }\end{array}$ & $\begin{array}{r}.193^{* * *} \\
.000 \\
\end{array}$ & $\begin{array}{r}-.133^{* *} \\
.001 \\
\end{array}$ & $\begin{array}{l}.230^{* *} \\
.000 \\
\end{array}$ & $\begin{array}{l}.228^{* *} \\
.000 \\
\end{array}$ & $\begin{array}{r}.448^{* *} \\
.000 \\
\end{array}$ & $\begin{array}{l}.505^{* *} \\
.000 \\
\end{array}$ & $\begin{array}{l}.504^{* *} \\
.000\end{array}$ & $\begin{array}{l}.520^{* *} \\
.000 \\
\end{array}$ & $\begin{array}{l}.608^{* *} \\
.000 \\
\end{array}$ & $\begin{array}{l}.474^{* *} \\
.000 \\
\end{array}$ & 1 & \\
\hline $\begin{array}{l}\text { Continu } \\
\text { Commit }\end{array}$ & $\begin{array}{l}\text { Pearson } \\
\text { Correlation } \\
\text { Sig. (2-tailed) }\end{array}$ & $\begin{array}{r}.227^{* *} \\
.000\end{array}$ & $\begin{array}{r}-.100^{* *} \\
.010\end{array}$ & $\begin{array}{l}.393^{* *} \\
.000\end{array}$ & $\begin{array}{l}.406^{* *} \\
.000\end{array}$ & $\begin{array}{l}.036 \\
.354\end{array}$ & $\begin{array}{l}.055 \\
.156 \\
\end{array}$ & $\begin{array}{l}.110^{* *} \\
.004\end{array}$ & $\begin{array}{l}.043 \\
.263\end{array}$ & $\begin{array}{l}.065 \\
.095\end{array}$ & $\begin{array}{l}.583^{* *} \\
.000\end{array}$ & $\begin{array}{r}.456^{* *} \\
.000\end{array}$ & 1 \\
\hline
\end{tabular}

Note: ${ }^{*} \mathbf{p}<.05 ; * * \mathbf{p}<.01$; 
Table 2. One way ANOVA using dichotomous variable GENDER

\begin{tabular}{l|l|l}
\hline Variable & F-statistic & Sig. \\
\hline School Satisfaction & .121 & .728 \\
\hline $\begin{array}{l}\text { Commitment (women more } \\
\text { committed to program) }\end{array}$ & 11.830 & $.001^{* *}$ \\
\hline $\begin{array}{l}\text { Initiating Structure (imposed } \\
\text { structure has no effect) }\end{array}$ & 1.67 & .197 \\
\hline $\begin{array}{l}\text { Consideration (being consid-erate } \\
\text { matters) }\end{array}$ & 4.092 & .043 \\
\hline $\begin{array}{l}\text { Affective Commitment (women } \\
\text { report liking the program better) }\end{array}$ & 5.636 & $.018^{*}$ \\
\hline $\begin{array}{l}\text { Behavioral Commitment (women } \\
\text { more likely to commit to curricular } \\
\text { structure as imposed) }\end{array}$ & 11.898 & $.001^{* *}$ \\
\hline $\begin{array}{l}\text { Continuance Commitment (women } \\
\text { more likely to desire finishing the } \\
\text { program) }\end{array}$ & 6.701 & $.010^{* *}$ \\
\hline
\end{tabular}

Table 3. ANOVA, Satisfaction Predicting Commitment and its Components

\begin{tabular}{l|l|l}
\hline \multicolumn{1}{c|}{ Variable } & \multicolumn{1}{c|}{ F } & \multicolumn{1}{c}{ Sig. } \\
\hline Commitment & 76.4 & $.000^{* *}$ \\
\hline Affective Commitment & 13.4 & $.000^{* *}$ \\
\hline Behavioral Commitment & 332.5 & $.000^{* *}$ \\
\hline Continuance Commitment & 2.779 & .096 \\
\hline
\end{tabular}

Table 4. ANOVA, Leader Behaviors Predicting Commitment and its Components

\begin{tabular}{l|l|ll}
\hline \multicolumn{1}{c|}{ Variable } & \multicolumn{1}{c|}{ F } & \multicolumn{1}{c}{ Sig. } \\
\hline Commitment & 8.059 & .000 \\
\hline Affective Commitment & 8.606 & .000 \\
\hline Behavioral Commitment & 1.739 & .801 \\
\hline Continuance Commitment & .189 & .828 \\
\hline
\end{tabular}

Table 5. ANOVA, Initiating Structure Predicting Commitment and its Components

\begin{tabular}{l|l|l}
\hline \multicolumn{1}{c|}{ Variable } & \multicolumn{1}{c|}{ F } & \multicolumn{1}{c}{ Sig. } \\
\hline Commitment & 2.01 & .325 \\
\hline Affective Commitment & 1.8 & .421 \\
\hline Behavioral Commitment & 2.4 & .541 \\
\hline Continuance Commitment & 38.619 & $.000 * *$ \\
\hline
\end{tabular}

Table 6. ANOVA, Consideration Predicting Commitment and its Components

\begin{tabular}{l|l|l}
\hline \multicolumn{1}{c|}{ Variable } & \multicolumn{1}{|c}{ F } & \multicolumn{1}{c}{ Sig. } \\
\hline Commitment & 14.023 & $.000^{* *}$ \\
\hline Affective Commitment & 15.456 & $.000^{* *}$ \\
\hline Behavioral Commitment & 41.809 & $.000^{* *}$ \\
\hline Continuance Commitment & .769 & .381 \\
\hline
\end{tabular}


Table 7. ANOVA, Effectiveness Predicting Commitment and its Components

\begin{tabular}{l|l|l}
\hline \multicolumn{1}{c|}{ Variable } & \multicolumn{1}{c}{ F } & \multicolumn{1}{c}{ Sig. } \\
\hline Commitment & 18.559 & $.000^{* *}$ \\
\hline Affective Commitment & 17.109 & $.000^{* *}$ \\
\hline Behavioral Commitment & 24.153 & $.000^{* *}$ \\
\hline Continuance Commitment & 3.45 & .061 \\
\hline
\end{tabular}

Table 8. Stepwise Regression, Demographic Variables Predicting Commitment and its Components

\begin{tabular}{|c|c|c|c|}
\hline Variable & Age & Gender & Months in Job \\
\hline $\begin{array}{l}\text { Commitment } \\
F=5.615, \\
\text { Sig. }=.000\end{array}$ & $\begin{array}{l}\mathrm{T}=.675 \\
\text { Sig. }=.500\end{array}$ & $\begin{array}{l}\mathrm{T}=11.830 * * \\
\text { Sig. } 05\end{array}$ & $\begin{array}{l}\mathrm{T}=1.253 \\
\text { Sig. }=.211\end{array}$ \\
\hline $\begin{array}{l}\text { Affective } \\
\text { Commitment } \\
\mathrm{F}=3.692 \\
\text { Sig. }=.006\end{array}$ & $\begin{array}{l}\mathrm{T}=.776 \\
\text { Sig. }=.438\end{array}$ & $\begin{array}{l}\mathrm{T}=-3.089 \\
\text { Sig, }=.002\end{array}$ & $\begin{array}{l}\mathrm{T}=1.178 \\
\text { Sig. }=.556\end{array}$ \\
\hline $\begin{array}{l}\text { Behavioral } \\
\text { Commitment } \\
F=7.795 \\
\text { Sig. }=.000\end{array}$ & $\begin{array}{l}\mathrm{T}=2.725 \\
\text { Sig. }=.006\end{array}$ & $\begin{array}{l}\mathrm{T}=-3.371 \\
\text { Sig, }=.001\end{array}$ & $\begin{array}{l}\mathrm{T}=2.072 \\
\text { Sig. }=.039\end{array}$ \\
\hline $\begin{array}{l}\text { Continuance } \\
\text { Commitment } \\
F=7.273 \\
\text { Sig. }=.000\end{array}$ & $\begin{array}{l}\mathrm{T}=-1.488 \\
\text { Sig. }=.138\end{array}$ & $\begin{array}{l}\mathrm{T}=-1.46 \\
\mathrm{Sig},=.146\end{array}$ & $\begin{array}{l}\mathrm{T}=-.685 \\
\text { Sig. }=.494\end{array}$ \\
\hline
\end{tabular}

Table 9. "Hi" Variables Related to Work, ProfSat, Rewards, Graduation and Classmates

\begin{tabular}{|c|c|c|c|c|}
\hline Work & Prof Sat & Rewards & Graduation & Classmates \\
\hline Fascinating * & Solicits advice & $\begin{array}{l}\text { Adequate } \\
\text { feedback* }\end{array}$ & $\begin{array}{l}\text { Quick } \\
\text { progression* }\end{array}$ & Stimulating \\
\hline Satisfactory & Recognition* & Satisfactory & Merit rewarded & Ambitious* \\
\hline Good & Tactful & $\begin{array}{l}\text { Provides } \\
\text { emotional } \\
\text { security* }\end{array}$ & $\begin{array}{l}\text { Good possibility } \\
\text { graduation* }\end{array}$ & Responsible* \\
\hline Creative & Influential & Available * & $\begin{array}{l}\text { Good possibility } \\
\text { job. * }\end{array}$ & Fast \\
\hline Fashionable* & Actualized* & & & Intelligent \\
\hline Pleasing & $\begin{array}{l}\text { Tells me where I } \\
\text { am }\end{array}$ & & & Smart \\
\hline \multirow[t]{2}{*}{ Satisfying * } & Intelligent & & & Active \\
\hline & Accessible & & & Loyal \\
\hline
\end{tabular}

* = "significant predictor commitment*, usually a positive relationship, e.g. the more fascination the more commitment." 
Table 10. "Lo" Variables Related to Work, ProfSat, Rewards, Graduation and Classmates

\begin{tabular}{|c|c|c|c|c|}
\hline Work & Prof Sat & Rewards & Graduation & Classmates \\
\hline Routine & Hard to please & Not high enough & $\begin{array}{l}\text { Limited } \\
\text { opportunity }\end{array}$ & Boring \\
\hline Boring* & Impolite & Low* & Low opportunity & Slow* \\
\hline Tedious & No supervision & $\begin{array}{ll}\text { Keeps } \\
\text { insecure* }\end{array}$ & $\begin{array}{l}\text { Unfair grading } \\
\text { policies* }\end{array}$ & $\begin{array}{l}\text { No } \\
\text { intelligence* }\end{array}$ \\
\hline Difficult & Bad temper* & $\begin{array}{lll}\text { Less than I } \\
\text { deserve }\end{array}$ & & $\begin{array}{l}\text { Easy to make } \\
\text { enemies }\end{array}$ \\
\hline Frustrating* & Irritating & Unavailable & & $\begin{array}{l}\text { Talk too } \\
\text { much* }\end{array}$ \\
\hline Simple & Stubborn & & & $\begin{array}{l}\text { Too } \\
\text { competitive }\end{array}$ \\
\hline \multirow[t]{4}{*}{ Never ending } & $\mathrm{Bad}$ & & & Unpleasant \\
\hline & Neglectful* & & & No privacy \\
\hline & Lazy* & & & $\begin{array}{l}\text { Of limited } \\
\text { interests }\end{array}$ \\
\hline & & & & $\begin{array}{l}\text { Hard to make } \\
\text { friends }\end{array}$ \\
\hline
\end{tabular}

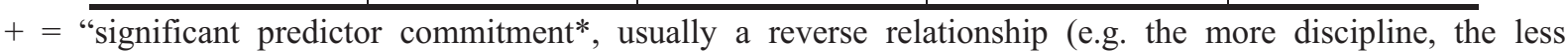
commitment."

Table 11. Collective effects of satisfaction on commitment and commitment components

\begin{tabular}{|c|c|c|c|}
\hline Sat Characteristic & Lo & $\mathrm{Hi}$ & All \\
\hline Sat Work & $\begin{array}{l}\text { Affective - } \\
\text { Behavioral }+ \\
\text { Continuance }+\end{array}$ & $\begin{array}{l}\text { Affective - } \\
\text { Behavioral }+ \\
\text { Continuance }+\end{array}$ & $\begin{array}{l}\text { Affective - } \\
\text { Behavioral }+ \\
\text { Continuance }+\end{array}$ \\
\hline Sat Prof & $\begin{array}{l}\text { Affective - } \\
\text { Behavioral }+ \\
\text { Continuance }+\end{array}$ & $\begin{array}{l}\text { Affective - } \\
\text { Behavioral }+ \\
\text { Continuance }+\end{array}$ & $\begin{array}{l}\text { Affective - } \\
\text { Behavioral }+ \\
\text { Continuance }+\end{array}$ \\
\hline $\begin{array}{l}\text { Sat Rewards (predicts no } \\
\text { commitment main effect) }\end{array}$ & $\begin{array}{l}\text { Affective - } \\
\text { Behavioral - } \\
\text { Continuance - }\end{array}$ & $\begin{array}{l}\text { Affective - } \\
\text { Behavioral - } \\
\text { Continuance - }\end{array}$ & $\begin{array}{l}\text { Affective - } \\
\text { Behavioral - } \\
\text { Continuance - }\end{array}$ \\
\hline Sat Graduate Potential & $\begin{array}{l}\text { Affective }+ \\
\text { Behavioral - } \\
\text { Continuance - }\end{array}$ & $\begin{array}{l}\text { Affective - } \\
\text { Behavioral - } \\
\text { Continuance }+\end{array}$ & $\begin{array}{l}\text { Affective - } \\
\text { Behavioral - } \\
\text { Continuance - }\end{array}$ \\
\hline Sat Classmates & $\begin{array}{l}\text { Affective - } \\
\text { Behavioral + } \\
\text { Continuance - }\end{array}$ & $\begin{array}{l}\text { Affective - } \\
\text { Behavioral }+ \\
\text { Continuance - }\end{array}$ & $\begin{array}{l}\text { Affective - } \\
\text { Behavioral + } \\
\text { Continuance - }\end{array}$ \\
\hline
\end{tabular}

